\title{
EFEKTIVITAS PENDEKATAN PEMECAHAN POLYA TERHADAP KEMAMPUAN PEMECAHAN MASALAH MATEMATIKA SISWA KELAS XI SMA NEGERI 1 KONTUNAGA
}

\author{
Wa Ode Sarniati ${ }^{1)}$ Zamsir $^{2)}$, Laode Ahmad Jazuli ${ }^{3)}$ \\ ${ }^{1,2,3)}$ Jurusan Pendidikan Matematika FKIP Universitas Halu Oleo \\ Email: ${ }^{1)}$ waodesarniati95@gmail.com; zamsir@uho.ac.id; jazulimedsos@gmail.com
}

\begin{abstract}
Abstrak
Penelitian ini merupakan penelitian eksperimen dengan rancangan One-Group Pretest-Posttest Design. Penelitian ini bertujuan untuk melihat efektivitas pendekatan pemecahan Polya dalam meningkatkan kemampuan pemecahan masalah matematika siswa. Populasi dalam penelitian ini adalah seluruh siswa kelas XI.IPA SMA Negeri 1 Kontunaga yang terdiri dari tiga kelas paralel. Teknik pengambilan sampel menggunakan teknik simple random sampling. Dari cara tersebut, dipilih satu kelas sebagai sampel, yakni kelas XI IPA 3 sebagai kelas eksperimen. Teknik pengumpulan data dalam penelitian ini dilakukan dengan pemberian instrumen penelitian berupa lembar observasi dan intrumen tes kemampuan pemecahan masalah matematika siswa berbentuk tes uraian. Teknik analisis data mengunakan analisis statistik deskriptif dan analisis inferensial. Berdasarkan analisis data diperoleh kesimpulan bahwa pendekatan pemecahan Polya efektif digunakan dalam meningkatkan kemampuan pemecahan masalah matematika siswa. Hal ini ditunjukkan pada jumlah siswa yang mendapatkan nilai kemampuan pemecahan masalah matematika siswa berada pada kategori sedang hingga tinggi yaitu mencapai $75 \%$.
\end{abstract}

Kata Kunci: pemecahan polya, pemecahan masalah matematika, pembelajaran matematika

\section{THE EFFECTIVENESS OF POLYA'S SOLVING APPROACH ON THE MATHEMATICAL PROBLEM SOLVING ABILITY OF CLASS XI HIGH SCHOOL STUDENTS NEGERI 1 KONTUNAGA}

\begin{abstract}
This research is an experimental study with a One-Group Pretest-Posttest Design. This study aims to see the effectiveness of Polya's solving approach in improving students' mathematical problem solving abilities. The population in this study were all students of class XI.IPA SMA Negeri 1 Kontunaga which consisted of three parallel classes. The sampling technique used simple random sampling technique. From this method, one class was chosen as the sample, namely class XI IPA3 as the experimental class. The data collection technique in this study was carried out by providing research instruments in the form of observation sheets and instruments for tests of students' mathematical problem solving abilities in the form of essay tests. The data analysis technique used descriptive statistical analysis and inferential analysis. Based on the data analysis, it was concluded that the Polya solving approach was effective in improving students' mathematical problem solving abilities. This is shown in the number of students who get the value of students' math problem solving abilities in the medium to high category, reaching $75 \%$.
\end{abstract}

Keywords: polya's solving approach, math problem solving, mathemtics learning 


\section{Pendahuluan}

Pendidikan merupakan hal pokok yang sangat diperlukan manusia untuk mempersiapkan diri dalam menghadapi dunia yang terus bergerak. Pendidikan adalah usaha sadar yang dilakukan manusia untuk meningkatkan kemampuan diri dengan potensipotensi pribadi yang dimiliki. Tujuan pendidikan nasional seperti yang tercantum dalam UU No. 20 Tahun 2003 yaitu untuk mengembangkan potensi peserta didik agar menjadi manusia yang beriman dan bertaqwa kepada tuhan Yang Maha Esa, berakhlak mulia, sehat, berilmu, cakap, kreatif, mandiri, dan menjadi warga negara yang demokratis serta bertanggung jawab. Dengan itu, melalui pendidikan diharapkan akan lahir sumber daya manusia berkualitas yang mampu membangun kehidupan masyarakat, bangsa, dan negara ke arah yang lebih baik.

Pelaksanaan Kurikulum 2013 pada saat ini, selain penekanannya lebih pada peningkatan nilai-nilai budaya bangsa dan pendidikan karakter, peningkatan aspek kognitif, berpikir, dan bernalar juga tidak terabaikan. Hal ini dapat dilakukan melalui pembelajaran setiap bidang studi termasuk pembelajaran matematika.

Pembelajaran matematika diarahkan untuk mengembangkan kemampuan matematis, ini sesuai dengan tujuan yang diharapkan oleh National Council of Teacher Mathematics (NCTM) dalam pembelajaran matematika. NCTM (2000) menetapkan bahwa terdapat lima standar kemampuan matematis yang harus dimiliki oleh siswa, yaitu kemampuan pemecahan masalah (problem solving), kemampuan komunikasi (communication), kemampuan koneksi (connection), kemampuan penalaran (reasoning), dan kemampuan representasi (representation). Dari kelima kemampuan tersebut, terlihat bahwa kemampuan pemecahan masalah matematis merupakan hal penting yang seharusnya dimiliki oleh setiap siswa untuk mempermudah pembelajaran matematika.

Menurut Badan Standar Nasional Pendidikan (BSNP, 2006), pemecahan masalah merupakan kompetensi strategi yang ditunjukkan siswa dalam memahami, memilih pendekatan dan strategi pemecahan, dan menyelesaikan model untuk menyelesaikan masalah. Mengingat pentingnya penguasaan pamecahan masalah, pemerintah memasukkan aspek pemecahan masalah menjadi salah satu bagian dari tujuan mata pelajaran matematika di sekolah. Menurut Wahab (2007:94) pemecahan masalah matematika adalah suatu strategi yang dapat mendorong dan menumbuhkan kemampuan anak dalam menemukan dan mengolah informasi.

Menurut Polya (dalam Zahriah, dkk., 2016:152), menyatakan bahwa tahapan yang dapat dilakukan oleh siswa untuk memecahkan masalah, yaitu memahami masalah (understanding the problem), menyusun rencana (devising a plan), melaksanakan rencana (carrying out the plan), dan melakukan pengecekan (looking back).

Berdasarkan latar belakang yang telah dikemukakan, maka tujuan dari penelitian ini adalah untuk mengetahui pembelajaran matamatika dengan menggunakan pendekatan pemecahan polya efektif digunakan dalam meningkatkan kemampuan pemecahan masalah matematika siswa kelas XI.IPA SMA Negeri 1 Kontunaga.

Faktor yang mempengaruhi keefektifan dalam pembelajaran yaitu kemampuan guru dalam menggunakan metode pembelajaran. Dimana metode pembelajaran dipengaruhi oleh faktor tujuan, siswa, situasi, fasilitas, dan pengajar itu sendiri. Menurut Sadiman dalam Trianto (2009: 20) keefektifan pembelajaran adalah hasil guna yang diperoleh setelah pelaksanaan kegiatan belajar mengajar. Soemosasmito dalam Trianto juga menyatakan bahwa suatu pembelajaran dapat dikatakan efektif apabila memenuhi beberapa persyaratan utama keefektifan pembelajaran, yaitu: (a) presentasi waktu belajar siswa yang tinggi dicurahkan terhadap KBM, (b) rata-rata perilaku melaksanakan tugas yang tinggi diantara siswa, (c) ketepatan antara kandungan materi pembelajaran dengan kemampuan siswa (orientasi keberhasilan belajar) diutamakan, dan (d) mengembangkan suasana belajar yang akrab dan positif, mengembangkan struktur kelas yang mendukung butir (b) tanpa mengabaikan butir (d).

Dengan demikian dapat disimpulkan bahwa keefektifan pembelajaran adalah tingkat keberhasilan dalam pencapaian tujuan pembelajaran. Keefektifan dari penggunaan pendekatan pemecahan Polya dalam pembelajaran matematika dapat dilihat dari tingkat kemandirian belajar dan kemampuan pemecahan masalah matematika. Jika tingkat 
kemandirian belajar dan kemampuan pemecahan masalah matematika siswa setelah diajar menggunakan pendekatan pemecahan Polya lebih tinggi dari pada sebelum diajar dengan pendekatan pemecahan Polya, maka pendekatan pemecahan Polya dikatakan efektif.

Fransiska Saadi (2013 : 7) mengatakan bahwa indikator dalam efektivitas belajar adalah: (a) Ketuntasan belajar, ketuntasan belajar dapat dilihat dari hasil belajar yang telah mencapai ketuntasan individual, yakni peserta didik telah memenuhi kriteria ketuntasan minimal (KKM) yang ditentukan oleh sekolah bersangkutan, (b) Aktivitas belajar peserta didik, aktivitas belajar peserta didik adalah proses komunikasi dalam lingkungan kelas, baik proses akibat dari hasil interaksi siswa dan guru atau peserta didik dengan peserta didik sehingga menghasilkan perubahan akademik, sikap, tingkah laku dan keterampilan, (c) Kemampuan guru dalam mengelolah pembelajaran, guru merupakan salah satu faktor yang mempengaruhi hasil pelaksanaan dalam pembelajaran yang telah diterapkan.

Istilah matematika diambil dari bahasa Yunani mathematike yang berarti relating to learning. Perkataan itu mempunyai akar kata mathema yang berarti pengetahuan atau ilmu. Berdasarkan kutipan Suherman (2003: 18), matematika berarti ilmu pengetahuan yang diperoleh dengan bernalar. Matematika terbentuk sebagai hasil pemikiran manusia yang berhubungan dengan ide, proses dan penalaran.

Menurut Johnson dan Myklebust (dalam Abdurrahman, 2003: 252), matematika adalah bahasa simbolis yang fungsi praktisnya untuk mengeksperesikan hubungan-hubungan kuantitatif dan keruangan sedangkan fungsi teoritisnya adalah untuk memudahkan berpikir. Kline (Abdurrahman, 2003: 252), matematika merupakan bahasa simbolis dan ciri utamanya adalah penggunaan cara bernalar deduktif, tetapi juga tidak melupakan cara bernalar induktif.

Jadi, matematika merupakan salah satu disiplin ilmu yang terstruktur dan konsisten, mengolah logika dan pola pikir seseorang sehingga dapat digunakan sebagai alat dan bahasa disiplin ilmu lainnya.

Berdasarkan pendapat para pakar pendidikan di atas dapat disimpulkan bahwa belajar adalah suatu proses perubahan tingkah laku yang mengakibatkan bertambahnya pengetahuan, keterampilan, nilai dan sikap yang diperoleh dari interaksi individu dengan lingkungannya yang sifatnya relative permanen.

Menurut Kamus Besar Bahasa Indonesia (2002: 17), pembelajaran adalah proses, cara, perbuatan menjadikan orang atau makhluk hidup belajar. Sedangkan menurut UU Guru dan Dosen (2006: 52), pembelajaran adalah proses interaksi peserta didik dengan pendidik dan sumber belajar pada suatu lingkungan belajar. Menurut Hamalik (2008: 3), pembelajaran adalah prosedur dan metode yang ditempuh oleh pengajar untuk memberikan kemudahan bagi peserta didik untuk melakukan kegiatan belajar secara aktif dalam rangka mencapai tujuan pembelajaran. Dimyati dan Mudjiono (2002: 157) menyebutkan pembelajaran adalah proses yang diselenggarakan oleh guru untuk membelajarkan siswa dalam belajar bagaimana belajar memperoleh dan memproses pengetahuan, keterampilan dan sikap. Dengan demikian pembelajaran bisa diartikan sebagai pendidikan dalam lingkup persekolahan atau proses sosialisasi individu siswa dengan sekolah, seperti guru, sumber atau fasilitas, dan teman sesama siswa. Menurut Suherman dalam Jihad dan Haris (2013 : 11) pembelajaran merupakan suatu proses yang terdiri dari kombinasi dua aspek, yaitu: belajar tertuju kepada apa yang harus dilakukan oleh siswa, dan mengajar berorientasi pada apa yang harus dilakukan oleh guru sebagai pemberi pelajaran. Kedua aspek ini akan berkolaborasi secara terpadu menjadi suatu kegiatan pada saat terjadi interaksi antara guru dengan siswa, serta antara siswa dengan siswa disaat pembelajaran sedang berlangsung. Dengan kata lain, pembelajaran pada hakikatnya merupakan proses komunikasi antar peserta didik dengan pendidik serta antar peserta didik dalam rangka perubahan sikap.

Jadi, pembelajaran merupakan suatu proses yang ditempuh oleh pendidik untuk memberikan kemudahan pada peserta didik dalam upaya menata dan memberi nuansa agar proses belajar dapat mencapai tujuan pembelajaran.

Menurut Suyitno (2004: 2), pembelajaran matematika adalah suatu proses atau kegiatan guru mata pelajaran matematika dalam mengajarkan matematika kepada para siswanya, yangdidalamnya terkandung upaya guru untuk menciptakan iklim dan pelayanan terhadap kemampuan, potensi, minat, bakat, dankebutuhan siswa tentang matematika yang amat beragam agar terjadi interaksi optimal 
antar guru dengan siswa serta antara siswa dengan siswa dalam mempelajari matematika.

Berdasarkan uraian di atas, tujuan pembelajaran matematika di sekolah ditekankan agar siswa mampu memahami konsep matematika, mampu menggunakan penalaran dalam menyampaikan gagasan matematika dan memecahkan masalah matematika.

Hensberry dan Jacobbe (dalam Agus Mustika dan Nanci, 2017) mengatakan bahwa, "the heuristics are intended to help students go beyond current ways of thinking about a problem... Polya's heuristics can be thought of as providing a language to help problem solvers think back about their problem solving experiences, artinya model Polya merupakan suatu prosedur analitis yang dimaksudkan untuk membantu siswa agar bisa melebihi batasan cara berpikir siswa sekarang mengenai suatu masalah".

Aisyah, dkk (2007) menyebutkan bahwa pada tahap understanding the problem (memahami masalah) dalam kegiatan pemecahan masalah diarahkan untuk membantu siswa menetapkan apa yang diketahui pada permasalahan dan apa yang ditanyakan.

Pada tahap devising a plan (menyusun rencana), Billstein, dkk (dalam Agus Mustika dan Nanci, 2017) mengatakan bahwa hal yang dapat dilakukan yaitu, "examine related problems and determine if the same technique applied to them can be applied to the current problem". Artinya, siswa dapat meninjau kembali masalah serupa yang pernah dipecahkan sebelumnya dan menentukan apakah teknik yang sama dapat diterapkan pada masalah yang sedang dipecahkan sekarang. Selain itu, siswa juga dapat mengerjakan masalah serupa yang lebih sederhana untuk menambah wawasan untuk dapat menemukan solusi dari permasalahan utama. Tahap ketiga adalah tahap melaksanakan rencana penyelesaian. Pada tahap ini rencana yang telah disusun akan dilanjutkan sesuai dengan cara-cara penyelesaian masalah yang diberikan. Pengalaman pemecahan masalah sangat berperan besar pada tahap ini. Tahap terakhir adalah tahap memeriksa kembali, pada tahap ini indikasi tercapainya tahap memeriksa kembali adalah peserta didik memeriksa jawaban yang telah diberikan, jika memungkinkan dilakukan metode penghitungan kembali (Argarini, 2018).

Dari penjelasan diatas dapat disimpulkan bahwa pendekatan pemecahan
Polya adalah pendekatan dengan prosedur analitis, yaitu memahami masalah, merencanakan pemecahan masalah, melaksanakan rencana penyelesaian dan memeriksa kembali, yang dimaksudkan untuk membantu siswa agar bisa melebihi batasan cara berpikir siswa sekarang mengenai suatu masalah.

Salah satu tujuan pembelajaran matematika menurut BNSP (2006: 102) adalah memahami konsep matematika, menjelaskan keterkaitan antar konsep dan mengaplikasikan konsep atau logaritma secara luwes, akurat, efisien, dan tepat dalam pemecahan masalah. Masalah dapat didefinisikan sebagai suatu situasi puzzling, dimana sesorang tertarik untuk mengetahui penyelesaiannya, akan tetapi strategi penyelesaiannya tidak serta merta tersedia, lebih jelasnya suatu masalah memuat (1) keinginan untuk mengetahui, (2) tidak adanya cara yang jelas untuk mendapatkan penyelesaiannya, dan (3) memerlukan suatu usaha dalam menyelesaikannya (Husna, 2013: 83).

Dari beberapa pendapat di atas, dapat disimpulkan bahwa masalah adalah suatu persoalan/pertanyaan yang membutuhkan penyelesaian/jawaban yang tidak bisa diperoleh sebelum memiliki prosedur tertentu untuk menyelesaikannya. Sedangkan masalah matematika adalah suatu pertanyaan atau soal matematika yang cara penyelesaiannya harus diselesaikan melalui prosedur tertentu.

Pemecahan masalah adalah suatu proses untuk mengatasi kesulitan yang dihadapi untuk mencapai suatu tujuan yang hendak dicapai. Suherman dkk (2003: 83), pemecahan masalah merupakan bagian kurikulum matematika yang sangat penting karena dalam proses pembelajarannya maupun penyelesaiannya, siswa dimungkinkan memperoleh pengalaman menggunakan pengetahuan serta keterampilan yang sudah dimiliki untuk diterapkannya pada pemecahan masalah atau soal yang bersifat tidak rutin. Menurut Hudojo (dalam Aisyah, 2009: 5), pemecahan masalah pada dasarnya adalah prosesyang ditempuh oleh seseorang untuk menyelesaikan masalah yang dihadapinya sampai masalah itu tidak lagi menjadi masalah baginya. Hudojo (dalam Suwangsih, dkk., 2006: 126) mengemukakan bahwa penyelesaian masalah dapat diartikan sebagai penggunaan matematika baik untuk matematika itu sendiri maupun aplikasi matematika dalam kehidupan sehari-hari dan ilmu pengetahuan yang lain 
secara kreatif untuk menyelesaikan masalahmasalah yang belum kita ketahui penyelesaiannya ataupun masalah-masalah yang belum kita kenal.

Kemampuan pemecahan masalah sangat penting artinya bagi siswa dan masa depannya. Menurut Suharsono (2009: 53), bahwa kemampuan pemecahan masalah dalam batasbatas tertentu, dapat dibentuk melalui bidang studi dan disiplin ilmu yang diajarkan. Kemampuan berasal dari kata mampu yang berarti sanggup dan bisa melakukan sesuatu. Kemampuan pemecahan masalah dalam hal ini adalah kesanggupan siswa dalam memecahkan masalah matematik (Rofiqoh, 2015: 25).

Kantowski dan Rustyawati (Puspitasari, 2014) mengatakan bahwa setelah tahun 1970-an terjadi perkembangan pengertian dari Problem Solving. Bila sebelumnya diartikan sebagai pemecahan masalah verbal maka sekarang termasuk didalamnya adalah pemecahan masalah non rutin dan masalah situasi dunia nyata. Masalah non rutin adalah masalah yang belum ada arah yang jelas bagi penyelesaiannya dan belum ada algoritma yang dapat digunakan untuk menyelesaikannya. Untuk itu seorang harus menggunakan segala pengetahuan yang dimilikinya untuk menemukan solusi dari permasalahan tersebut, dengan melakukan try and error untuk memperoleh penyelesaian masalah tersebut.

Problem Solving, melibatkan konteks yang bervariasi yang berasal dari penghubungan masalah-masalah dalam kehidupan sehari-hari untuk situasi matematika yang ditimbulkan. Belajar pemecahan masalah pada hakekatnya adalah belajar berpikir (learning to think) atau belajar bernalar (learning to reason), yaitu berpikir dan bernalar mengaplikasikan pengetahuan yang telah diperoleh sebelumnya untuk menyelesaikan masalah baru yang sebelumnya belum pernah dijumpai (Noer, 2007: 24)

Dalam penelitian ini, kemampuan pemecahan masalah matematika yang dimaksud mengacu pada kemampuan pemecahan soal-soal atau masalah matematika rutin atau tidak rutin yang tidak dapat segera dipecahkan dengan mengikuti aspek-aspek penyelesaian; memahami masalah, menyelesaikan masalah dan menjawab masalah. Ketiga aspek ini sejalan dengan indikator yang digunakan untuk mengukur kemampuan pemecahan masalah matematika siswa, yaitu: mengidentifikasi kecukupan data untuk memecahkan masalah dan membuat model matematik dari suatu situasi atau masalah sehari-hari dan menyelesaikannya (memahami masalah); memilih dan menerapkan strategi untuk menyelesaikan masalah matematika dan atau di luar matematika (menyelesaikan masalah); dan menjelaskan atau menginterpretasikan hasil sesuai permasalahan asal (menjawab masalah).

Penelitian Agus Mustika dan Nanci (201 7) menyimpulkan bahwa terdapat perbedaan kemampuan pemecahan masalah matematika antara kelompok siswa yang mengikuti pembelajaran menggunakan model Polya dan kelompok siswa yang mengikuti pembelajaran tidak menggunakan model Polya.

Salah satu tujuan pembelajaran matematika adalah agar siswa memiliki kemampuan pemecahan masalah. Kemampuan pemecahan masalah merupakan salah satu faktor penting dari tujuan pembelajaran karena memberi pengetahuan semata-mata kepada siswa tidak akan banyak menolongnya dalam kehidupan sehari-hari, sehingga dalam pembelajaran sebaiknya dapat mengembangkan sikap dan kemampuan peserta didik yang dapat membantu untuk menghadapi persoalanpersoalan di masa mendatang secara kreatif.

Untuk mengembangkan kemampuan pemecahan masalah siswa dalam pembelajaran matematika, perlu dilaksanakan pembelajaran yang memberi kesempatan kepada siswa untuk mengembangkan kemampuan pemecahan masalahnya.

Beberapa cara untuk mengatasi permasalahan tersebut, dapat digunakan berbagai strategi pembelajaran yang dapat membangun keaktifan siswa dalam mengembangkan pengetahuan atau pemahaman yang dimilikinya dengan cara mengidentifikasi masalah pemahaman atau pengetahuan awal siswa dengan pemahaman atau pengetahuan baru didapat. Salah satu pembelajaran yang memberi kesempatan kepada siswa untuk dapat mengembangkan kemampuan pemecahan masalahnya adalah pendekatan pembelajaran pemecahan Polya.

Pendekatan pemecahan Polya adalah pendekatan dengan prosedur analitis, yaitu memahami masalah, merencanakan pemecahan masalah, melaksanakan rencana penyelesaian dan memeriksa kembali, yang dimaksudkan untuk membantu siswa agar bisa melebihi 
batasan cara berpikir siswa sekarang mengenai suatu masalah.

Dengan pendekatan pemecahan Polya diharapkan siswa memiliki kemampuan dalam menghadapi permasalahan yang ada dalam pelajaran matematika, dan juga permasalahan dalam kehidupan. Karena salah satu tujuan pembelajaran matematika adalah siswa memiliki kemampuan pemecahan masalah. Jika proses pembelajaran dengan pendekatan pemecahan Polya berjalan dengan baik maka diharapkan dapat meningkatkan prestasi belajar matematika siswa, terutama dalam kemampuan pemecahan masalah matematika siswa.

Berdasarkan teori-teori, penelitian yang relevan dan kerangka berpikir yang sudah dikemukakan di atas, maka dapat dinyatakan hipotesis dalam penelitian ini, yaitu "pembelajaran matematika dengan menggunakan pendekatan pemecahan Polya efektif meningkatkan kemampuan pemecahan masalah matematika siswa kelas XI.IPA SMA Negeri 1 Kontunaga". Adapun hipotesis statistik yang digunakan, yaitu: Keterangan:

$$
\mathrm{H}_{0}: \mu_{D} \leq 0 \text { lawan } \mathrm{H}_{1}: \mu_{D}>0
$$

$\mathrm{H}_{0}=$ Pembelajaran matematika dengan menggunakan pendekatan pemecahan Polya tidak efektif meningkatkan kemampuan pemecahan masalah matematika siswa.

$H_{1}=$ Pembelajaran matematika dengan menggunakan pendekatan pemecahan Polya efektif meningkatkan kemampuan pemecahan masalah matematika siswa.

$\mu_{D}=$ rata-rata selisih hasil belajar matematika siswa sebelum dan sesudah diajar dengan pendekatan pemecahan Polya.

\section{Metode}

Jenis penelitian ini adalah penelitian eksperimen dengan perlakuan pendekatan pemecahan Polya. Penelitian ini dilaksanakan di kelas X1 SMA Negeri 1 Kontunaga semester ganjil tahun ajaran 2018/2019. Populasi dalam penelitian ini adalah seluruh siswa kelas X1.IPA SMA Negeri 1 Kontunaga yang berjumlah 83 siswa dan tersebar dalam 3 kelas paralel. Sampel dalam penelitian ini dipilih dengan menggunakan teknik simple random sampling. Sampel yang dibutuhkan dalam penelitian adalah sebanyak satu kelas. Berdasarkan teknik pengambilan sampel tersebut, diperoleh kelas
X1.IPA3 dengan jumlah siswa 27 siswa sebagai sampel penelitian.

Variabel yang digunakan dalam penelitian ini adalah variabel bebas dan variabel terikat. Variabel bebas (Independen) pada penelitian ini yaitu pendekatan pemecahan Polya (X). Dalam penelitian ini variabel terikatnya adalah kemampuan pemecahan masalah matematis siswa (Y) yang diajar dengan menggunakan pendekatan pemecahan Polya.

Penelitian ini menggunakan desain penelitian One-Group Pretest-Posttest Design, yaitu penelitian yang dilaksanakan pada satu kelompok saja tanpa ada kelompok pembanding. Alur dari desain penelitian ini adalah kelas yang digunakan untuk penelitian (kelas eksperimen) diberi pretets kemudian dilanjutkan dengan pemberian perlakuan, yaitu penerapan pendekatan pemecahan Polya, setelah itu diberi Posttest. Desain penelitian ini menurut Sugiyono (2016: 111) digambarkan sebagai berikut:

Tabel 1

Desain Penelitian

\begin{tabular}{ccc}
\hline Pretest & Treatment & Posttest \\
\hline $\mathrm{O}_{1}$ & $\mathrm{X}$ & $\mathrm{O}_{2}$ \\
\hline
\end{tabular}

Keterangan :

$\mathrm{O}_{1}=$ Tes awal (Pretest) dilakukan sebelum siswa diberikan perlakuan penerapan pendekatan pemecahan Polya.

$\mathrm{X}=$ Perlakuan (Treatment) diberikan kepada siswa berupa pembelajaran menggunakan pendekatan pemecahan Polya.

$\mathrm{O}_{2}=$ Tes akhir (Posttest) dilakukan setelah siswa diberikan perlakuan pendekatan pemecahan Polya.

Penelitian ini mempunyai beberapa instrumen, yaitu lembar observasi dan tes kemampuan pemecahan masalah matematis siswa. Lembar observasi aktivitas guru digunakan untuk mengamati kegiatan guru dalam mengelolah pembelajaran, sedangkan lembar observasi aktivitas siswa digunakan untuk mengamati kegiatan yang dilakukan oleh siswa dalam mengikuti pembelajaran. Lembar observasi yang dibuat mengacu pada rencana pelaksanaan pembelajaran (RPP) yang telah dibuat sebelumnya. Setiap aktivitas yang diamati dalam penelitian ini mengacu pada sintaks pendekatan pemecahan Polya. Tes yang diberikan pada 
siswa dalam penelitian ini berbentuk esai (uraian) agar siswa dapat menggunakan kalimatkalimat yang mereka susun sendiri untuk memecahkan soal/masalah yang ada. Untuk memperoleh data dalam penelitian ini dilaksanakan tes hasil kemampuan pemecahan masalah matematis siswa. Tes ini dilakukan kepada kelas X1.IPA3, setelah kelas tersebut diberikan perlakuan dengan tujuan mendapatkan data akhir. Dari tes tersebut dilakukan penskoran terhadap jawaban siswa untuk tiap butir soal.

Menurut Szetela dkk (Arini Puspitasari, 2014: 41-42) untuk memperoleh skor pada tes kemampuan pemecahan masalah matematis siswa, maka disusun pedoman penskoran yang meliputi skor maksimum dan skor minimum untuk setiap butir soal. Pedoman penskoran yang digunakan adalah analytical scale for problem solving yang terdiri atas tiga bagian, yaitu memahami masalah, mayelesaikan masalah dan menjawab masalah.

Adapun cara perhitungan nilai akhir adalah sebagai berikut.

$\mathrm{N}=\frac{\text { skorperolehan }}{\text { skormaksimal }} \times 100$, dengan $N$ sebagai nilai akhir.

Uji validitas adalah suatu ukuran yang menunjukkan kesahihan atau tingkat kevalidan suatu instrumen. Analisis validitas penilaian panelis digunakan untuk mengetahui validitas konsep instrumen melalui penilaian panelis dengan menggunakan rumus:

$$
V=\frac{\sum n_{i}\left|i-l_{o}\right|}{[N(c-1)]}
$$

dalam Hanita, 2018)

(Aiken

dimana :

$V=$ Indeks validitas isi

$n_{i}=$ Cacah dari titik skala hasil penilaian rater

$i=$ Titik skala ke-I $(\mathrm{I}=1,2,3,4,5)$

$l_{o}=$ Titik skala terendah

$N=$ Jumlah rater $\left(\Sigma \mathrm{n}_{\mathrm{i}}\right)$

$c$ = Banyaknya titik skala

Nilai V terletak antara 0 dan 1 (valid $\geq 0,6$ ).

Suatu tes dikatakan reliabel jika hasil pengukuran yang dilakukan dengan menggunakan tes tersebut berulang kali terhadap subjek yang sama, senantiasa menunjukkan hasil yang tetap sama atau sifatnya stabil atau konsisten. Reliabilitas menunjukkan pada suatu pengertian bahwa suatu instrumen cukup dapat dipercaya untuk digunakan sebagai alat pengumpul data. Untuk mengetahui reliabilitas tes uraian digunakan rumus Alpha Cronbach sebagai berikut:

$r_{11}=\frac{k}{k-1}\left[1-\frac{\sum s_{i}^{2}}{s_{t}{ }^{2}}\right]$

Dengan rumus varian, yaitu:

$s_{i}^{2}=\frac{\sum x^{2}-\frac{\left(\sum x_{i}\right)^{2}}{N}}{N}$

Keterangan:

$r_{11} \quad$ : reliabilitas instrumen

K : banyaknya butir soal

$\sum S_{i}{ }^{2}$ : jumlah varian semua butir soal

$\boldsymbol{s}_{t}{ }^{2}$ : varians total

$\boldsymbol{N}$ : banyak siswa

$\sum x^{2}$ : jumlah skor total kuadrat

$\left(\sum x\right)^{2}$ : kuadrat jumlah skor

Uji validitas adalah suatu ukuran yang menunjukkan kesahihan atau tingkat kevalidan suatu instrumen. Untuk tes uraian, validitas butir tesnya dihitung dengan menggunakan rumus korelasi product moment dengan angka kasar sebagai berikut.

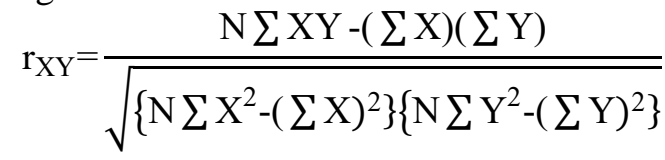

Keterangan :

$\mathrm{r}_{\mathrm{XY}}=$ koefisien korelasi antara $\mathrm{X}$ dan $\mathrm{Y}$

$\mathrm{N}$ = banyaknya subjek/peserta didik uji coba

$\sum X=$ jumlah skor tiap butir soal

$\sum \mathrm{Y}=$ jumlah skor total

$\sum X^{2}=$ jumlah kuadrat skor butir soal

$\sum \mathrm{Y}^{2}=$ jumlah kuadrat skor total

$\sum X Y=$ jumlah perkalian skor tiap butir soal dan skor total (Arikunto, 2009: 72)

Adapun kriteria pengujian sebagai berikut.

- Jika $r_{X Y} \geq r_{\text {tabel }}$ dengan $\alpha=0,05$ maka butir soal tersebut valid

- Jika $r_{X Y}<r_{\text {tabel }}$ dengan $\alpha=0,05$ maka butir soal tersebut tidak valid.

Pengumpulan data dalam penelitian ini didapatkan dengan pemberian instrumen penelitian berupa lembar observasi dan tes 
kemampuan pemecahan masalah matematika siswa. Lembar observasi akan digunakan pada setiap pertemuan. Hasilnya dipergunakan untuk memperoleh data tentang aktivitas/partisipasi guru dan siswa. Untuk memperoleh data dalam penelitian ini dilaksanakan tes hasil kemampuan pemecahan masalah matematis siswa. Tes kemampuan pemecahan masalah matematis siswa dilakukan sebanyak dua kali yaitu pretest dan posttest. Pretest dilakukan sebelum memberikan perlakuan pada kelas yang diteliti dan posttest dilakukan setelah memberikan perlakuan kepada kelas yang diteliti. Setelah kegiatan pembelajaran menggunakan pendekatan pemecahan polya, maka diadakan posttest untuk mengetahui hasil kemampuan pemecahan masalah matematis siswa. Dari tes tersebut dilakukan penskoran terhadap jawaban siswa untuk tiap butir soal. Adapun pedoman penskoran yang digunakan untuk menilai kemampuan pemecahan masalah matematika siswa yaitu pedoman penskoran dari Puspitasari pada tabel 3.3. Selanjutnya, hasil pekerjaan siswa dikumpulkan oleh peneliti untuk diperiksa dan dikoreksi serta diberi nilai. Nilai dari hasil pekerjaan siswa tersebut kemudian dijadikan data dalam penelitian ini.

Dalam penelitian ini, peneliti menggunakan teknik analisis data kuantitatif, Adapun data kuantitatif ini di analisis menggunakan analisis statistik. Analisis statistik yang digunakan adalah analisis statistik deskriptif dan analisis statistik inferensial.

Analisis deskriptif dimaksudkan untuk mendeskripsikan hasil belajar siswa melalui skor rata-rata yang diperoleh siswa kelas eksperimen. Analisis deskriptif hanya melihat gambaran sampel dalam bentuk rata-rata $(\bar{x})$, median $(M e)$, modus $(M o)$, minimum, maksimum, standar deviasi dan varians.

Analisis inferensial dimaksudkan untuk menguji hipotesis rata-rata hasil belajar matematika siswa efektif dengan pembelajaran matematika menggunakan pendekatan pemecahan polya. Namun sebelum melakukan uji hipotesis, terlebih dahulu melalui tahapan uji prasyarat untuk melakukan uji hipotesis, yaitu uji normalitas.

Uji normalitas data dimaksudkan untuk mengetahui apakah data yang diperoleh berasal dari populasi yang berdistribusi normal atau tidak. Uji normalitas merupakan uji pendahuluan dari perhitungan analisis, jika data yang diperoleh dikatakan normal maka data tersebut akan dilanjutkan dengan statistik parametrik. Jika data yang diperoleh dikatakan tidak normal maka data tersebut akan dilanjutkan dengan statistik non parametrik. Uji normalitas pada kelas eksperimen menggunakan uji Kolmogorov -Smirnov.

Untuk mengetahui apakah pembelajaran matematika dengan menggunakan pendekatan pemecahan Polya efektif terhadap kemampuan pemecahan masalah matematika siswa, digunakan rumus uji-t satu sampel data berpasangan secara manual dan menggunakan aplikasi SPSS.

Rumus uji-t yang digunakan adalah:

$$
t=\frac{\bar{B}}{\left(\frac{S_{B}}{\sqrt{n}}\right)}
$$

Dimana:

$\bar{B}=$ rata-rata selisih hasil belajar pretest dan posttest

$S_{B}=$ simpangan baku selisih pretest dan posttest $\mathrm{n}=$ jumlah sampel

(Sudjana, 2005:242)

Kriteria pengujian yaitu tolak $\mathrm{H}_{0}$ jika $t_{\text {hitung }} \geq t_{(1-\alpha)}$ dengan $\mathrm{dk}=(\mathrm{n}-1)$. Taraf kesalahan $\alpha=0,05$. Untuk harga-harga t lainnya $\mathrm{H}_{0}$ ditolak.

\section{Hasil}

Dari hasil analisis skor belajar siswa pada menunjukan bahwa persentase pada pretest tidak mencapai kriteria tuntas, yaitu $16,66 \%$. Sedangkan persentase posttest mencapai kriteria tuntas, yaitu $75 \%$. Hal tersebut menunjukkan bahwa pendekatan pemecahan Polya efektif terhadap kemampuan pemecahan masalah matematika siswa.

Hasil observasi pengelolaan pembelajaran oleh guru selama pembelajaran persentase keberhasilan pengelolaan pembelajaran pada pertemuan pertama mencapai 75\%. Pada pertemuan ini, peneliti masih melakukan penyesuaian terhadap tahap-tahap pelaksanaan pendekatan pemecahan Polya, sehingga beberapa langkah-langkah pembelajaran yang direncanakan tidak dapat dilaksanakan, seperti memberikan apersepsi dengan mereview materi berkaitan, tidak memotivasi siswa bahwa materi yang dipelajari hari ini di kuasai dengan baik dapat membantu siswa pada materi berikutnya dan menyelesaikan 
masalah berkaitan serta guru tidak sempamemberikan pekerjaan rumah (PR) kepada siswa akibat alokasi waktu pembelajaran telah habis.

Dari hasil observasi tersebut, terlihat bahwa pengelolaan pembelajaran oleh guru mengalami fluktuasi mengingat pendekatan pembelajaran yang baru diterapkan peneliti, namun pada akhir penerapannya peneliti mampu menerapkan pendekatan pembelajaran dengan baik.

Persentase keaktifan siswa pada pertemuan pertama mencapai 71,1\%. Pada pertemuan tersebut, mayoritas siswa menolak untuk belajar dengan metode kelompok karena pada pembelajaran sebelumnya mereka jarang dihadapkan dengan model belajar secara diskusi, sehingga kerjasama antar siswa dalam kelompok menjadi tidak maksimal. Selain itu, banyak siswa yang masih malu-malu untuk bertanya kepada teman kelompoknya atau kepada guru. Siswa juga terkesan "malu-malu" dalam mengungkapkan ide mereka dalam forum diskusi sehingga proses diskusi belum berjalan dengan baik.

Persentase keaktifan siswa pada pertemuan kedua mencapai $88,2 \%$. Pada pertemuan kedua ini, siswa sudah tidak malumalu lagi untuk bekerja sama dengan teman kelompoknya sehingga siswa terlihat antusias mengikuti pembelajaran. Keberhasilan ini disebabkan oleh siswa yang sudah mau bekerja sama dengan anggota kelompok dan mau berbagi dengan anggota kelompok lain. Tentu, hal ini menjadi hasil refleksi dari pertemuan pertama. Meskipun diakhir pertemuan, siswa tidak diberi kesempatan untuk menyimpulkan materi yang telah dipelajari karena keterbatasan waktu. Kemudian, pada pertemuan ketiga, persentase keaktifan siswa menurun menjadi $82,9 \%$. Hal ini terjadi karena masih banyak siswa yang belum mampu menyelesaikan masalah dalam LKS sehingga peneliti harus benar-benar membimbing siswa yang mengalami kesusahan tersebut. Karena waktu habis pada saat menyelesaikan masalah dalam LKS sehingga pada saat proses diskusi selesai, peneliti tidak memberikan kesempatan kepada siswa untuk memberikan tanggapan terhadap hasil diskusi pada tahap tersebut dan siswa tidak diberi kesempatan untuk menyimpulkan karna waktu telas habis. Meskipun pada pertemuan ketiga ini persentase tidak mengalami peningkatan namun tahap-tahap pembelajaran yang telah direncanakan sudah cukup baik terlaksana.

Persentase keaktifan siswa pada pertemuan keempat meningkat, yaitu mencapai 90,8\%. Pada pertemuan keempat ini, keterlaksanaan pembelajaran siswa sudah lebih baik dari pertemuan sebelumnya, namun masih ada siswa yang tidak berinteraksi dan berdiskusi dengan anggota kelompok serta tidak mampu menemukan sendiri penyelesaian suatu masalah. Kemudian, berdasarkan hasil refleksi dari pertemuan pertama, kedua, ketiga dan keempat tersebut, setiap tahapan pada pertemuan kelima tersebut dilaksanakan dengan baik dengan keaktifan siswa meningkat yaitu mencapai 97,74\% dalam pelaksanaan pembelajaran yang direncanakan. Namun persentase tidak mencapai $100 \%$ disebabkan masih ada sebagian kecil siswa yang tidak bertanya kepada teman atau Guru tentang hal-hal yang kurang jelas. Siswa sudah terbiasa dengan pembelajaran yang menggunakan pendekatan pemecahan Polya sehingga masalah-masalah dalam LKS mampu diselesaikan dengan baik.

Berdasarkan uraian diatas dapat disimpulkan bahwa siswa memerlukan waktu untuk beradaptasi terhadap suatu pembelajaran yang mereka anggap baru,hal tersebut dapat dilihat dari peningkatan persentase ketercapaian indikator yang diamati pada setiap pertemuan.

Hasil analisis deskriptif nilai tes kemampuan pemecahan masalah matematika siswa dengan menggunakan aplikasi SPSS diperoleh data kemampuan pemecahan masalah matematika siswa terlihat bahwa kemampuan pemecahan masalah matematika siswa pada pretest diperoleh nilai rata-rata kemampuan pemecahan masalah matematika siswa sebelum diajar menggunakan pendekatan pemecahan Polya sebesar 56,75 sedangkan kemampuan pemecahan masalah matematika siswa pada posttest diperoleh nilai rata-rata kemampuan pemecahan masalah matematika siswa yang diajar dengan menggunakan pendekatan pemecahan Polya sebesar 74,91. Median untuk pretest sebesar 52 dan untuk posttest sebesar 80 . Modus (Mode) untuk pretest sebesar 52 dan untuk posttest sebesar 80. Standar deviasi (simpangan baku) sebesar 10,645 untuk pretest dan 10,299 untuk posttest. Adapun varians pada saat pretest adalah sebesar 113,326 dan varians pada saat posttest adalah sebesar 106,080. Nilai minimum sebesar 48 untuk pretest dan 50 untuk 
posttest sedangkan untuk nilai maksimumpretest adalah sebesar 84 dan posttest sebesar 88 .

Berdasarkan analisis deskripsinya diperoleh selisih rata-rata pretest dan posttest $\left(\mu_{D}\right)$ sebesar 18,167. Selain itu, siswa yang tuntas pada pretest sebanyak 4 orang dan siswa yang tuntas pada posttest sebanyak 18 orang. Hal tersebut menunjukkan bahwa ada pengaruh yang signifikan, sehingga mengindikasikan bahwa dilanjutkan ke uji-t untuk mengetahui apakah pendekatan pemecahan Polya efektif terhadap kemampuan pemecahan masalah matematika siswa.

Uji normalitas dilakukan untuk mengetahui bahwa data awal sampel yang diambil berasal dari populasi yang berdistribusi normal atau tidak. Uji normalitas dilakukan pada selisih data pretest dan posttest untuk kelas eksperimen.

Hipotesis statistik yang digunakan:

$\mathrm{H}_{0}$ : Sampel berasal dari populasi yang berdistribusi normal

$\mathrm{H}_{1}$ : Sampel berasal dari populasi yang tidak berdistribusi normal

Kriteria pengambilan keputusan adalah jika Asymp. Sig. (2-tailed) $\geq \alpha=0,05$ maka terima $\mathrm{H}_{0}$ artinya data berasal dari populasi yang berdistribusi normal. Jika Asymp. Sig. (2-tailed) $<\alpha=0,05$ maka tolak $\mathrm{H}_{0}$ artinya data berasal dari populasi yang tidak berdistribusi normal diketahui bahwa Asymp. Sig. (2-tailed) data Pretest-Posttest adalah 0,941 $>\alpha$ (dengan $\alpha=$ $0,05)$, sehingga $\mathrm{H}_{0}$ diterima. Dengan demikian, dapat disimpulkan bahwa data tersebut berdistribusi normal.

Setelah melakukan uji normalitas, maka diperoleh data Pretest-Posttest berdistribusi normal. Dengan demikian, untuk menguji efektivitas pembelajaran matematika melalui pendekatan pemecahan Polya terhadap kemampuan pemecahan masalah matematika siswa digunakan uji-t satu sampel data berpasangan (paired sampel $t$-test).

Adapun hipotesis yang diuji dalam penelitian ini adalah:

Keterangan:

$$
\mathrm{H}_{0}: \mu_{D} \leq 0 \text { lawan } \mathrm{H}_{1}: \mu_{D}>0
$$

$\mathrm{H}_{0}=$ Pembelajaran matematika dengan menggunakan pendekatan pemecahan Polya tidak efektif meningkatkan kemampuan pemecahan masalah matematika siswa

$$
\begin{aligned}
& \mathrm{H}_{1}=\text { Pembelajaran matematika dengan } \\
& \text { menggunakan pendekatan } \\
& \text { pemecahan Polya efektif } \\
& \text { meningkatkan kemampuan } \\
& \text { pemecahan masalah matematika } \\
& \text { siswa }
\end{aligned}
$$

\section{Pembahasan}

Berdasarkan uraian analisis data hasil penelitian dan pengujian hipotesis di atas, berikut ini dikemukakan pembahasan terhadap beberapa temuan yang berhubungan dengan kemampuan pemecahan masalah matematika siswa setelah diajar dengan menggunakan pendekatan pembelajaran pemecahan Polya.

Jenis penelitian ini adalah penelitian eksperimen tentang efektivitas pembelajaran matematika melalui pendekatan pemecahan Polya terhadap kemampuan pemecahan masalah matematika siswa pada materi program linear kelas XI.IPA SMA Negeri 1 Kontunaga. Penelitian ini mulai dilaksanakan pada tanggal 8 September 2018 sampai tanggal 29 September 2018. Waktu pembelajaran dalam pelaksanaan penelitian adalah 14 jam pelajaran. Total pertemuan dalam penelitian ini sebanyak 7 kali pertemuan. 5 kali pertemuan untuk proses pembelajaran, 1 kali pertemuan untuk pretest dan 1 kali pertemuan untuk posttest. Masingmasing pretest dan posttest diberikan waktu selama 120 menit. Kelas eksperimen diberikan pretest materi matriks sebelum diberi perlakuan kemudian diberikan posttest setelah diberi perlakuan pendekatan pemecahan Polya dengan materi program linear.

Penelitian ini menggunakan sampel yaitu kelas XI IPA3 SMA Negeri 1 Kontunaga. Kelas tersebut diberi perlakuan pendekatan pemecahan Polya. Desain penelitian pada kelas tersebut diawali dengan pemberian pretest, perlakuan (pembelajaran matematika dengan pendekatan pemecahan Polya) dan diakhiri dengan pemberian posttest. Pendekatan pembelajaran pemecahan Polyamemiliki empat tahap pembelajaran, yaitu pemahaman masalah, perencanaan strategi, pelaksanaan strategi dan pengecekan kembali.

Pada tahap pemahaman masalah, merupakan tahap dimana siswa 
mampu memahami apa yang diketahui dan ditanyakan pada soal yang diberikan. Tahap perencanaan strategi bertujuan agar siswa mampu menentukan rumus/ cara/ metode yang bisa digunakan untuk menyelesaikan soal yang diberikan, khususnya pada materi program linear. Pada tahap ini dalam pembelajaran, guru membantu siswa mengorganisasikan tugas belajar, yaitu siswa secara berkelompok berdiskusi mengerjakan lembar kegiatan siswa (LKS) dan memberikan kesempatan kepada siswa untuk menemukan berbagai cara penyelesaian dari masalah yang diberikan. Pada tahap ini terjadi diskusi antar siswa dalam kelompok. Pada tahap ini, seluruh indikator kemampuan pemecahan masalah matematika siswa dapat dikembangkan melalui soal-soal yang diberikan. Dalam tahap pelaksanaan strategi, siswa mampu menggunakan cara/ rumus/ metode yang telah direncanakan untuk menyelesaikan soal yang diberikan dan guru memperhatikan diskusi yang sedang berlangsung dalam tiap kelompok dan mencatat respon-respon siswa, serta bertindak sebagai fasilitator. Artinya, jika siswa merasa kesulitan dalam kegiatan menemukan kemungkinankemungkinan cara penyelesaian dan mendorong siswa tersebut mengumpulkan informasi untuk mendapatkan pemecahan masalah.

Selanjutnya, pada tahap pengecekan kembali, siswa mengoreksi kembali jawaban yang telah diberikan dalam menyelesaikan soal untuk memastikan jawaban, kemudian perwakilan dari kelomok belajar diberikan kesempatan untuk mengemukakan konsep yang telah ditemukannya pada lembar kerja siswa (LKS) kepada kelompok yang lain, sehingga terjadi proses diskusi aktif dalam kelas. Guru memandu jalannya diskusi dan membantu siswa dalam merencanakan dan menyiapkan hasil karya yang sesuai seperti mosel-model pemecahan masalah untuk mengambil kesimpulan alternatif jawaban yang benar dari hasil pemecahan masalah yang dibuat masingmasing kelompok.

Dalam tahap akhir juga siswa menyimpulkan konsep-konsep yang sudah dipelajari dan diberikan bimbingan agar tidak terjadi salah pemahaman dan penafsiran dari konsep yang diajarkan. Kemudian, diberikan tugas rumah (PR) terhadap proses-proses yang siswa gunakan untuk menjadi latihan siswa dalam menyelesaikan soal yang sesuai dengan tujuan pembelajaran yang ingin dicapai.
Pada pertemuan di kelas pertama-tama dilakukan kegiatan pendahuluan, yang meliputi pemberian apersepsi, pemberian motivasi dan penyampain tujuan pembelajaran, kemudian dilakukan pembagian kelompok yang heterogen. Dalam proses pembelajaran di kelas, siswa di bagi menjadi lima kelompok dengan tiap kelompok beranggotakan 5-6 orang siswa. Kemudian setiap siswa diberikan bahan ajar dan LKS untuk dikerjakan secara berkelompok. Pada tahap ini, siswa diberikan pengarahan dan bimbingan melalui penjelasan atau pertanyaan yang mengarah pada penyelesaian masalah bila diminta langsung oleh siswa dengan memanfaatkan media pembelajaran. Setelah semua kelompok telah mengerjakan LKS yang diberikan sesuai dengan waktu yang ditetapkan, beberapa siswa dipilih mewakili kelompoknya tampil di depan kelas untuk mempresentasikan hasil kerja kelompoknya untuk ditanggapi oleh kelompok lain. Jika ada jawaban siswa yang keliru maka diberikan bantuan untuk mengambil kesimpulan alternatif jawaban yang benar dari hasil pemecahan masalah yang dibuat masingmasing kelompok. Diakhir pertemuan, siswa membuat kesimpulan dari materi yang telah dipelajari, kemudian ditutup dengan pemberian tugas yang dikerjakan dirumah.

Pada awal pelaksanaan perlakuan pada kelompok eksperimen mengalami sedikit hambatan. Siswa membutuhkan waktu untuk menyesuaikan diri dengan pendekatan pembelajaran yang baru diterapkan dikelas, terutama pada saat pembentukan kelompok, sehingga proses ini cukup menyita waktu pembelajaran. Siswa yang tidak terbiasa dengan pembentukan kelompok belajar, awalnya kurang antusias dalam proses pembelajaran ini. Beberapa siswa menunjukan sikap yang kurang bekerjasama dalam kelompok, sehingga tidak semua siswa aktif dalam kelompok belajar pada saat proses pembelajaran berlangsung. Hal ini mengakibatkan proses penyerapan materi pembelajaran oleh siswa kurang maksimal. Perlahan-lahan, hambatan-hambatan yang terjadi dapat diatasi dan diminimalisir. Walaupun beberapa pertemuan berikutnya, masih ada beberapa komponen pendekatan pembelajaran pemecahan Polya yang tidak terlaksana. Siswa dikontrol dan diarahkan dengan baik, sehingga siswa yang tadinya kurang antusias, merasa senang bekerjasama dalam kelompoknya. 
Pada pentemuan kedua dan pertemuanpertemuan selanjutnya, proses pembelajaran dapat berjalan dengan cukup baik dan lancar. Beberapa siswa juga masih mengalami kesulitan dalam menggalih dan mengolah informasi dari LKS dan sumber belajar lainnya, sehingga siswa tersebut belum mampu menemukan sendiri penyelesaian dari masalah yang diberikan. Namun dengan arahan dan bimbingan, siswa sudah mulai mengerti dengan pendekatan pemecahan Polya.

Selama lima kali pertemuan pembelajaran, diperoleh data aktivitas guru dan siswa dalam mengelolah dan mengikuti jalannya proses pembelajaran yang dilaksanakan pada kelas eksperimen dengan penerapan pendekatan pemecahan Polya. Keberhasilan pengelolaan pembelajaran oleh guru selama pembelajaran dengan pendekatan pemecahan Polya berkategori sangat baik. Berdasarkan lembar observasi, presentase pengelolaan pembelajaran oleh guru tidak pernah mencapai $100 \%$. Guru pengajar mengakui, penerapan pendekatan pemecahan Polya bukanlah hal yang mudah, sehingga dalam pelaksanaan pembelajaran, ada beberapa langkah yang direncanakan tidak dapat dilaksanakan. Juga, tidak jarang masalah yang dihadapi siswa tidak dapat diselesaikan dengan baik, disebabkan oleh ketidak-cakapan siswa dalam menyelesaikan soal-soal yang terdapat dalam lembar kerja siswa dan ketidakmampuan guru dalam mengunjungi setiap kelompok untuk membantu dan membimbing siswa saat diskusi berlangsung. Untuk itu, apabila siswa kesulitan menyelesaikan masalah, guru hanya menjelaskan proses penyelesaian masalah di papan tulis.

Berdasarkan hasil observasi aktivitas guru dan siswa, dapat dikatakan bahwa pencapaian keterlaksanaan pembelajaran tergolong berhasil karena presentase pencapaian keterlaksanaan pembelajaran bisa mencapai > $80 \%$.

Berdasarkan analisis deskripsinya terlihat bahwa kemampuan pemecahan masalah matematika siswa pada posttest diperoleh nilai rata-rata kemampuan pemecahan masalah matematika siswa setelah diajar menggunakan pendekatan pemecahan Polya lebih tinggi dari pada rata-rata kemampuan pemecahan masalah matematika siswa pada pretest. Selain itu, siswa yang tuntas pada pretest sebanyak 4 orang dan siswa yang tuntas pada posttest sebanyak 18 orang. Hal tersebut menunjukkan bahwa ada pengaruh yang signifikan, sehingga mengindikasikan bahwa dilanjutkan ke uji-t untuk mengetahui apakah pendekatan pemecahan Polya efektif terhadap kemampuan pemecahan masalah matematika siswa.

Rata-rata hasil belajar matematika siswa kelas XI.IPA SMA Negeri 1 Kontunaga setelah diajar dengan pendekatan pemecahan Polya efektif dari pada sebelum diajar dengan menggunakan pendekatan pemecahan Polya, ini dapat diketahui dengan melakukan uji hipotesis dengan uji-t satu sampel data berpasangan (paired sampel t-test). Sebelum melakukan uji hipotesis terlebih dahulu melakukan uji prasyarat yaitu uji normalitas data pada sampel. Berdasarkan uji normalitas data dengan menggunakan uji kolmogorof-smirnov diperoleh data dari rata-rata selisih pretest-posttest hasil belajar matematika siswa kelas XI.IPA SMA Negeri 1 Kontunaga berdistribusi normal.

Berdasarkan hasil uji normalitas, data berdistribusi normal. Maka tahap selanjutnya, melakukan uji hipotesis dengan cara manual dan menggunakan aplikasi SPSS menunjukan menolak $\mathrm{H}_{0}$. Maka, dapat disimpulkan bahwa pembelajaran matematika dengan menggunakan pendekatan pemecahan Polya efektiv digunakan dalam meningkatkan kemampuan pemecahan masalah matematika siswa kelas XI.IPA SMA Negeri 1 Kontunaga.

\section{Simpulan dan Saran}

\section{Simpulan}

Berdasarkan hasil penelitian dan pembahasan, maka dapat dikemukakan kesimpulan sebagai berikut:

1. Proses pembelajaran matematika dengan pendekatan pembelajaran pemecahan Polya pada siswa kelas XI.IPA.3 SMA Negeri 1 Kontunaga tergolong sangat baik pada keterlaksanaan pembelajaran oleh guru dan aktivitas siswa dalam pembelajaran. Hal ini ditunjukan dengan rata-rata persentase keterlaksanaan pembelajaran oleh guru dalam 5 kali pertemuan yaitu sebesar $80,5 \%$. Demikian pula dengan rata-rata persentase keaktifan siswa dalam 5 kali pertemuan yaitu sebesar $85,55 \%$.

2. Deskripsi kemampuan pemecahan masalah matematika siswa kelas XI IPA SMA Negeri 1 Kontunaga sebelum diajar dengan menggunakan pendekatan pemecahan 
Polya diperoleh nilai rata-rata sebesar 56,75. Standar deviasi sebesar 10,64 dan varians sebesar 113,326.

3. Deskripsi kemampuan pemecahan masalah matematika siswa kelas XI IPA SMA Negeri 1 Kontunaga setelah diajar dengan menggunakan pendekatan pemecahan Polya diperoleh nilai rata-rata sebesar 74,91. Standar deviasi sebesar 10,29 dan varians sebesar 106,08.

4. Berdasarkan hasil pengujian hipotesis dapat disimpulkan bahwa rata-rata kemampuan pemecahan masalah matematika siswa kelas XI SMA Negeri 1 Kontunaga setelah diajar dengan pendekatan pemecahan Polya lebih tinggi dari pada rata-rata kemampuan pemecahan masalah matematika siswa kelas XI SMA Negeri 1 Kontunaga sebelum diajar pendekatan pemecahan Polya. Dengan demikan, Pembelajaran matematika dengan meggunakan pendekatan pemecahan Polya efektif meningkatkan kemampuan pemecahan masalah matematika siswakelas XI SMA Negeri 1 Kontunaga.

\section{Saran}

Berdasarkan kesimpulan di atas, peneliti memberikan beberapa saran sebagai berikut:

1. Pendekatan pemecahan Polya sebaiknya dilaksanakan secara berkesinambungan,dilakukan dalam jangka waktu yang cukup panjang agar pengaruh pendekatan pembelajaran ini dapat dirasakan secara maksimal, khususnya terhadap kemampuan pemecahan masalah matematika siswa. Sebab inti dari pelaksanaan pendekatan pemecahan Polya ini adalah kemampuan pemecahan masalah materi matematika terhadap siswa.

2. Masalah-masalah yang dikemas pada pembelajaran matematika dengan pendekatan pemecahan Polya harus merupakan masalah konkret dan dapat dibayangkan oleh siswa. Oleh karenanya guru harus benar-benar kreatif untukmenemukan masalah-masalah konkret yang sesuai dengan kondisi materi matematika yang diajarkan di kelas, agar hasil belajar matematika siswa dapat dimaksimalkan.

3. Perlu adanya penelitian lebih lanjut yang relevan untuk memaksimalkan penerapan pendekatan pemecahan Polya terhadap kemampuan pemecahan masalah matematika siswa.

\section{Daftar Pustaka}

Abdurrahman, Mulyono. (2003). Pendidikan bagi Anak Berkesulitan Belajar. Jakarta: Rineka Cipta.

Aisyah, Nyimas, dkk. (2007). Pengembangan Pembelajaran Matematika SD. Direktorat Jenderal Pendidikan Tinggi. Jakarta: Departemen Pendidikan Nasional.

Aisyah, S. (2009). Perkembangan dan Konsep Dasar Pengembangan Anak Usia Dini. Jakarta: Universitas Terbuka.

A.M, Sardiman. (2009). Interaksi dan Motivasi Belajar Mengajar. Jakarta: Rajawali Pers.

Argarini, F.D. (2018). Analisis Pemecahan Masalah Berbasis Polya pada Materi Perkalian Vektor Ditinjau dari Gaya Belajar. Jurnal Matematika dan Pembelajaran. 6(1)., 34-40

Arikunto, Suharsimi. (2007). Metodologi Penelitian. Jakarta: Rineka Cipta.

BNSP. (2006). Panduan Penyusunan Kurikulum Tingkat Satuan Pendidikan. Jakarta: BNSP Depdiknas.

Depdiknas. (2002). Kamus Besar Bahasa Indonesia. Jakarta: Depdiknas.

Depdiknas. (2005). Kamus Besar Bahasa Indonesia. Jakarta: Depdiknas.

Dimyati dan Mudjiono. (2002). Belajar dan Pembelajaran. Jakarta: Rineka Cipta.

Hamalik, Oemar. (2008). Proses Belajar Mengajar. Jakarta: Bumi Aksara.

Jihad dan Haris. (2013). Evaluasi Pembelajaran. Yogyakarta: Multi Pressindo.

Mustika, Agus dan Nanci Riastini. (2017). Pengaruh Model Polya terhadap Kemampuan Pemecahan Masalah Matematika Siswa Kelas V SD. International Journal of Community Service Learning. 1(1), 31-38.

NCTM. (2000). Defining Problem Solving. [Online]. Tersedia di:http://www.learner.org/channel/courses 
/teachingmath/gradesk 2/session $03 /$ secti o_03_a.html. Diakses tanggal 21 April 2018.

Puspitasari, Arini. (2014). Efektivitas Pendekatan Open-Ended untuk Meningkatkan Kemampuan Pemecahan Masalah Matematika Siswa Kelas VIII SMP Negeri 13 Kendari. Jurnal Penelitian Pendidikan Matematika. 2(3)

Sugiyono. (2016). Metode Penelitian PendidikanPendekatan Kuantitatif, Kualitatifdan $R \& D$. Bandung: Alfabeta.

Suherman, E, dkk. (2003). Strategi Pembelajaran Matematika Kontemporer. Bandung: Universitas Pendidikan Indonesia.

Suwangsih, dkk. (2006). Model pembelajaran matematika, Bandung: UPI PRES
Suyitno, Amin. (2004). Dasar-dasar dan Proses Pembelajaran Matematika I. Semarang: FMIPA UNNES.

Trianto. (2009). Mendesain Model Pembelajaran Inovatif-Progresif: Konsep Landasan dan Implementasinya pada Kurikulum Tingkat Satuan Pendidikan(KTSP). Jakarta : Kencana Perdana Media Group.

Wahab. (2007). Metode dan Model-model Mengajar. Bandung: Alfabeta.

Zahriah, dkk. (2016). Penerapan Pemecahan Masalah Model Polya untuk Meningkatkan Kemampuan Analisis dan Hasil Belajar pada Materi Vektor di SMAN 1 Darul Imarah. Jurnal Pendidikan Sains Indonesia, 4(2), 151161: 